\title{
THE RELIABILITY FIRING TESTS OF THE SPECIAL AMMUNITION FOR 98 mm MORTAR M-98
}

\section{BADANIA NIEZAWODNOŚCIOWE AMUNICJI SPECJALNEJ DO 98 MM MOŹDZIERZA M-98}

\author{
Mariusz Magier, Piotr Ruliński \\ Wojskowy Instytut Techniczny Uzbrojenia \\ e-mail:magierm@witu.mil.pl rulińskip@witu.mil.pl
}

\begin{abstract}
In this paper, we present the constructions and reliability firing tests of the special ammunition for M-98 mortar. The research and development works was being carried out as part of the projects No. $347 / \mathrm{BO} / \mathrm{B}$ and $348 / \mathrm{BO} / \mathrm{B}$. Qualification firing tests was carried out in 2009 on the training ground in Nowa Dęba. Cartridges with the smoke projectile are intended for filling the area with smoke, indicating targets, protection of the maneuvers of own troops. Cartridges with the illuminating projectile are intended for lighting the area and indicating targets. Reliability firing tests was carried in November 2014 on the training ground in Nowa Dęba.
\end{abstract}

Keywords: mortar projectile, firing tests

Streszczenie: $\quad W$ pracy przedstawiono konstrukcje $i$ wyniki badań niezawodnościowych $98 \mathrm{~mm}$ naboi $z$ pociskiem dymnym $i$ oświetlającym do moździerza M-98. Prace badawczo-rozwojowe realizowano $w$ ramach projektów celowych $n r$ 347/BO/B i 348/BO/B. Badania kwalifikacyjne strzelaniem przeprowadzono w roku 2009 na poligonie w Nowej Dębie. Naboje z pociskiem dymnym sa przeznaczone do zadymiania terenu, wskazywania celów, ostony manewru wojsk własnych. Naboje z pociskiem oświetlajacym sa przeznaczone do oświetlania terenu $i$ wskazywania celów. Niezawodnościowe badania strzelaniem przeprowadzono w listopadzie 2014 roku na poligonie w Nowej Dębie.

Słowa kluczowe: pocisk moździerzowy, badania strzelaniem 
The reliability firing tests of the special ammunition for $98 \mathrm{~mm}$ mortar M-98 Badania niezawodnościowe amunicji specjalnej do $98 \mathrm{~mm}$ moździerza M-98

\section{Wstęp}

Przed II Wojną Światową w Polsce opracowano klika nowoczesnych konstrukcji moździerzy. Jedną $\mathrm{z}$ nich był $120 \mathrm{~mm}$ moździerz gwintowany na podwoziu dwukołowym (na wzór haubicy), z którego można było prowadzić ogień pociskami ze $120 \mathrm{~mm}$ armaty polowej na odległość do $5800 \mathrm{~m}$. Niestety nie zdążono wprowadzić go na uzbrojenie.

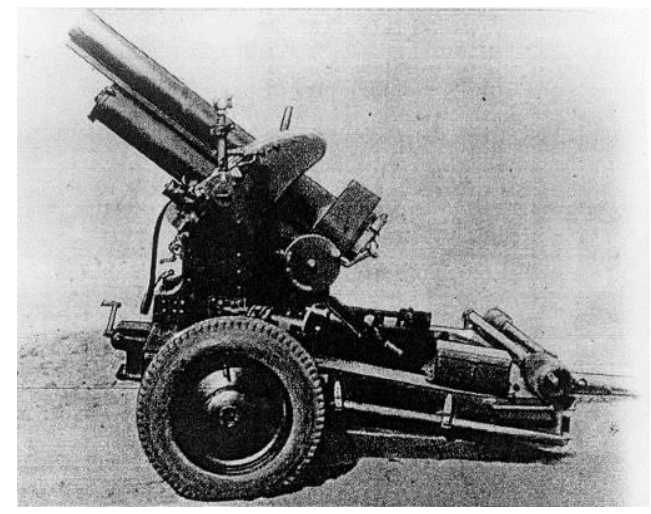

Rys. 1. 120 mm polski moździerz gwintowany (fot. MON)

W 1939 roku Wojsko Polskie dysponowało $81 \mathrm{~mm}$ moździerzami wz. 18/28 i wz. 31 oraz moździerzami ciężkimi wz. 32 kalibru $220 \mathrm{~mm}$ (27 szt.), wyposażonymi w przyczepę do przewozu lufy i ciągnik artyleryjski C7P. Podczas II W.Ś. Anglicy używali głównie $81 \mathrm{~mm}$ moździerzy Mk1 (donośność $1370 \mathrm{~m}$ ) i Mk2 (donośność $2560 \mathrm{~m}$ ). Amerykanie stosowali $60 \mathrm{~mm}$ moździerze M2 oraz $81 \mathrm{~mm}$ moździerze M1 (obie konstrukcje były produkowanie w USA na francuskiej licencji). $81 \mathrm{~mm}$ moździerz M1 montowano również na podwoziu halftracka - wersja M21. Niemiecka piechota wyposażona była w $50 \mathrm{~mm}$ moździerze wz.36 o donośności $500 \mathrm{~m}, 81 \mathrm{~mm}$ wz. 34 o donośności $2400 \mathrm{~m}$ oraz $120 \mathrm{~mm}$ moździerze wz. 42 o donośności $6000 \mathrm{~m}$ (nota bene skopiowane ze zdobycznych sowieckich $120 \mathrm{~mm}$ moździerzy wz. 38). Piechota rosyjska dysponowała moździerzami kalibru 50 mm M1940 i M1941, kalibru 82 mm wz. 1936, 1937, 1941 oraz moździerzami kalibru $120 \mathrm{~mm}$ wz. 38 i 43. Wiele opracowanych przed i podczas II W.Ś. moździerzy do dziś występuje w uzbrojeniu armii świata w formie oryginalnych konstrukcji lub ich modernizacji. Dynamiczny rozwój w latach 70-tych i 80-tych samobieżnych środków artyleryjskich, wpłynął także na rozwój moździerzy samobieżnych, spośród których możemy wyróżnić dwa ich rodzaje: wieżowe i bezwieżowe.

Moździerz wieżowy składa się z autonomicznego systemu wieżowego uzbrojonego w moździerz, osadzonego na podwoziu zaadoptowanym z gąsienicowego wozu bojowego lub KTO (Kołowego Transportera Opancerzonego). Zaletą systemu wieżowego jest przede wszystkim możliwość ochrony obsługi przed ostrzałem i odłamkami artyleryjskimi oraz przed oddziaływaniem broni ABC. Ponadto 
systemy wieżowe mogą prowadzić ogień na wprost np. amunicją przeciwpancerną (np. HEAT) do celów opancerzonych. Moździerze bezwieżowe charakteryzują się tym, że moździerz zamontowany jest w przestrzeni transportowej lub bojowej zaadoptowanego podwozia. Ponieważ niektóre konstrukcje moździerzy bezwieżowych wymagają prowadzenia ognia z odkrytego przedziału bojowego, obsługa może być narażona na ostrzał czy oddziaływanie odłamków artyleryjskich. Rozwojowe tendencje nie ominęły armii polskiej. W wyniku tego powstał w kraju $98 \mathrm{~mm}$ moździerz M-98. Jest drugim moździerzem na świecie (obok słowackiego) takiego kalibru, w związku z czym nie podlega ograniczeniem traktatu CFE-1. Znajduje się w uzbrojeniu oddziałów desantowo-szturmowych oraz piechoty górskiej i jest przeznaczony:

- do prowadzenia bezpośredniego wsparcia,

- obezwładniania i niszczenia sprzętu opancerzonego i siły żywej przeciwnika,

- stawiania zasłon dymnych i oświetlania pola walki.

Realizacja powyższych zadań wymaga zastosowania odpowiedniego rodzaju amunicji. Obecnie na wyposażeniu WP znajduje się amunicja odłamkowo-burząca i kasetowa z granatami kumulacyjno-odłamkowymi.

Opracowanie nowych naboi dymnych i oświetlających do moździerza M-98 było niezbędne do realizacji zadań ogniowych stawianych na współczesnym polu walki. Poniżej przedstawiono pociski dymny i oświetlający do $98 \mathrm{~mm}$ moździerza M-98 opracowane przez WITU i Z.M. DEZAMET S.A. w ramach realizacji w latach 2007-2010 projektów celowych $\mathrm{nr}$ 347/BO/O i 348/BO/O.

\section{Budowa naboi z pociskiem dymnym i oświetlajacym}

Pocisk dymny składa się $\mathrm{z}$ następujących zasadniczych części i zespołów: zapalnika (1), czepca balistycznego (2), zespołu zapalająco-wyrzucającego (3), korpusu (4), masy dymnej (5), spadochronu (6), dna (7), stabilizatora (8), ładunku zasadniczego (9) oraz ładunków dodatkowych (10).

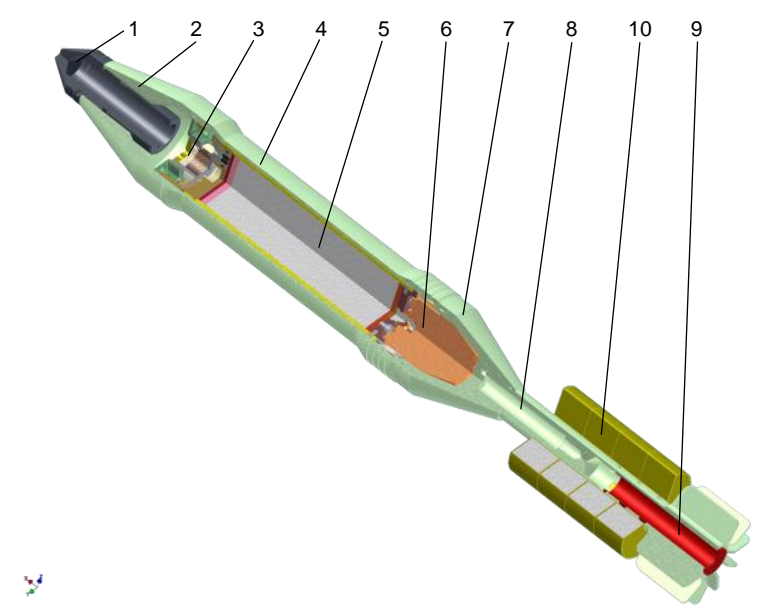

Rys. 2. Schemat moździerzowego pocisku dymnego 
The reliability firing tests of the special ammunition for $98 \mathrm{~mm}$ mortar M-98 Badania niezawodnościowe amunicji specjalnej do $98 \mathrm{~mm}$ moździerza M-98

Poszczególne elementy pocisku dymnego spełniają następujące funkcje:

- zapalnik czasowy wkręcony jest $\mathrm{w}$ otwór w czepcu balistycznym i po zaprogramowanym czasie od wylotu z lufy powoduje zadziałanie zespołu zapalająco-wyrzucającego,

- czepiec balistyczny nakręcany jest na korpus i zamyka go z przodu, a w otwór w jego przedniej części wkręcany jest zapalnik,

- zespół zapalająco-wyrzucający zawiera proch czarny. Zadaniem jego jest zainicjowanie palenia masy dymnej oraz wyrzucenie jej wraz ze spadochronem $\mathrm{z}$ wnętrza korpusu. Pełni również rolę amortyzatora w chwili uderzenia masy dymnej o ziemię,

- korpus służy do pomieszczenia masy dymnej i spadochronu oraz zapewnia prawidłowe uszczelnienie i prowadzenie pocisku w lufie,

- masa dymotwócza w czasie spalania powoduje powstanie dużej ilości dymu niezbędnej do ustawienia zasłony dymnej,

- spadochron po rozcaleniu pocisku wyhamowuje masę dymną do prędkości umożliwiającej jej prawidłowe funkcjonowanie po uderzeniu w ziemię,

- dno zamyka korpus z tyłu i łączy go ze stabilizatorem. Mieści również część spadochronu,

- stabilizator zapewnia poprawną stabilizację pocisku na torze lotu,

- ładunek zasadniczy włożony do otworu w stabilizatorze powoduje zapalenie ładunków dodatkowych umieszczonych na trzonie stabilizatora (ladunek zasadniczy umieszczony jest $\mathrm{w}$ tekturowej łusce zakończonej metalowym dnem, w którym obciśnięta jest spłonka zapalająca),

- ładunki dodatkowe służą do nadania pociskowi odpowiednich prędkości początkowych.

$\mathrm{Na}$ rys. 3 przedstawiony jest przekrój pocisku oświetlającego, składającego się $\mathrm{z}$ zespołów spełniających następujące funkcje:

- zapalnik czasowy, elektroniczny (1) wkręcony jest w „oko” czepca balistycznego (7) pocisku i po upływie nastawionego czasu powoduje zadziałanie zespołu rozcalającego (2) umieszczonego w czepcu balistycznym,

- zespół rozcalający zawiera ładunek z prochu czarnego, którego zadaniem jest zainicjowanie palenia masy oświetlającej (4) oraz jej wyrzucenie z wnętrza korpusu (3), może być integralną częścią zapalnika,

- korpus służy do pomieszczenia masy oświetlającej, spadochronu (5) z przecinakiem (6) i prowadzenia pocisku w lufie moździerza,

- masa oświetlająca służy do oświetlenia terenu w nocy (w pocisku oświetlającym przetwarza się energię chemiczną zgromadzoną w ładunkumasie oświetlającej $\mathrm{w}$ energię świetlną, dając strumień światła o dużym natężeniu),

- przecinak powoduje po określonym czasie, gdy już zespół oświetlający opuści pojemnik, przecięcie linki umożliwiającej całkowite rozwinięcie się spadochronu. 
- spadochron, po całkowitym rozwinięciu umożliwia powolne, ze stałą prędkością opadanie masy oświetlającej.

- dno (8) łączy korpus ze stabilizatorem (9) i w jego wnętrzu znajduje się spadochron,

- stabilizator zapewnia stabilizację pocisku na torze lotu,

- ładunek zasadniczy (10) powoduje zapalenie ładunków dodatkowych umieszczanych na stabilizatorze. Ładunek zasadniczy zazwyczaj umieszczony jest w tekturowej łusce i zawiera również spłonkę zapalającą.

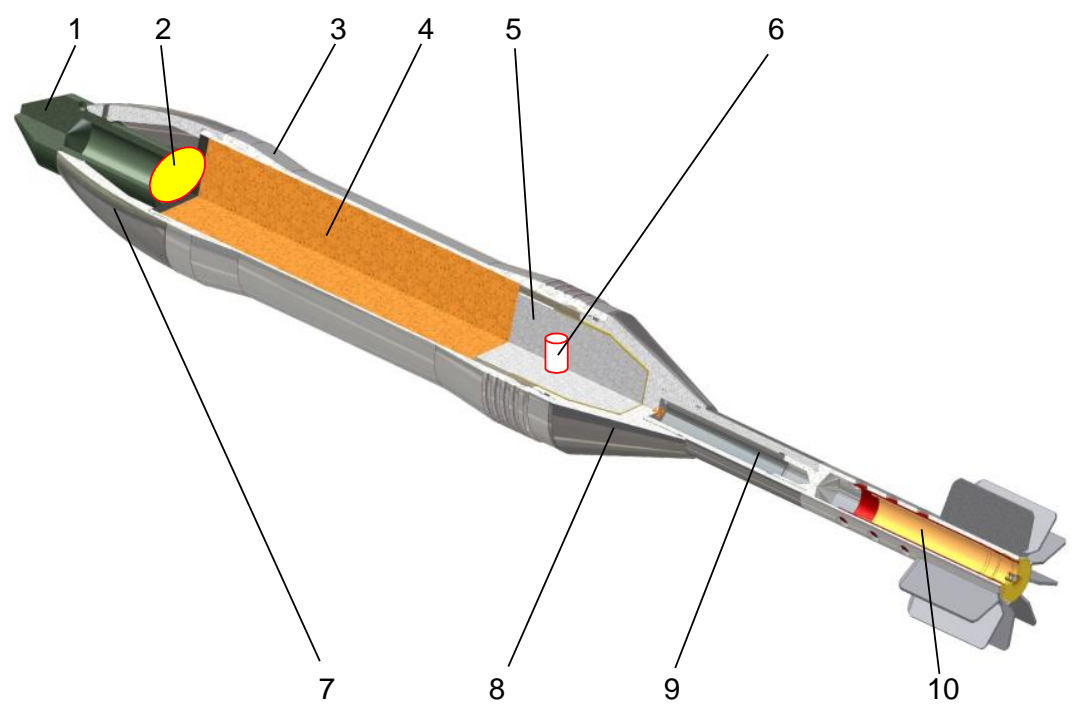

Rys. 3. Schemat moździerzowego pocisku oświetlającego

\section{Wyniki badań niezawodnościowych}

Badania certyfikacyjne strzelaniem naboi $\mathrm{z}$ pociskiem dymnym przeprowadził zespół badawczy wyznaczony przez Dyrektora WITU, w oparciu o „Program badań certyfikacyjnych naboi z pociskami oświetlającymi i dymnymi do $98 \mathrm{~mm}$ moździerza” wraz z „Metodyką Badań ...” - zatwierdzony przez Dyrektora Wojskowego Instytutu Technicznego i uzgodniony z Dyrektorem Technicznym DEZAMET S.A. pod względem zabezpieczenia amunicji. Przedstawiona w publikacji cześć badań dotyczyła wytrzymałości i funkcjonowania naboi $\mathrm{z}$ pociskiem oświetlających i dymnym do $98 \mathrm{~mm}$ moździerza $\mathrm{w}$ skrajnych temperaturach eksploatacji.

Badanie odporności na skrajne temperatury eksploatacji w ośrodku OBD WITU w Stalowej Woli. Badanie funkcjonowania strzelaniem odbyło się na terenie Ośrodka Szkolenia Poligonowego Wojsk Lądowych w Nowej Dębie. 
The reliability firing tests of the special ammunition for $98 \mathrm{~mm}$ mortar M-98 Badania niezawodnościowe amunicji specjalnej do $98 \mathrm{~mm}$ moździerza M-98

W trakcie badań sprawdzano:

- prawidłowość lotu pocisków,

- prędkość maksymalna pocisków,

- czas świecenia lub dymienia.

Parametry atmosferyczne podczas badania:

W dniu 12.11.2014 r. (mgła):

- temperatura powietrza:

- ciśnienie atmosferyczne:

- wilgotność:

- prędkość wiatru:

- kierunek wiatru:

W dniu 13.11.2014 r. :

- temperatura powietrza:

- ciśnienie atmosferyczne:

$7,5^{\circ} \mathrm{C}$

$991 \mathrm{hPa}$,

- prędkość wiatru:

$85 \%$

$3,2 \mathrm{~m} / \mathrm{s}$,

$126^{\circ}$.

- kierunek wiatru:

$11,4{ }^{\circ} \mathrm{C}$;

$992 \mathrm{hPa}$,

$3,7 \mathrm{~m} / \mathrm{s}$,

$313^{\circ}$.

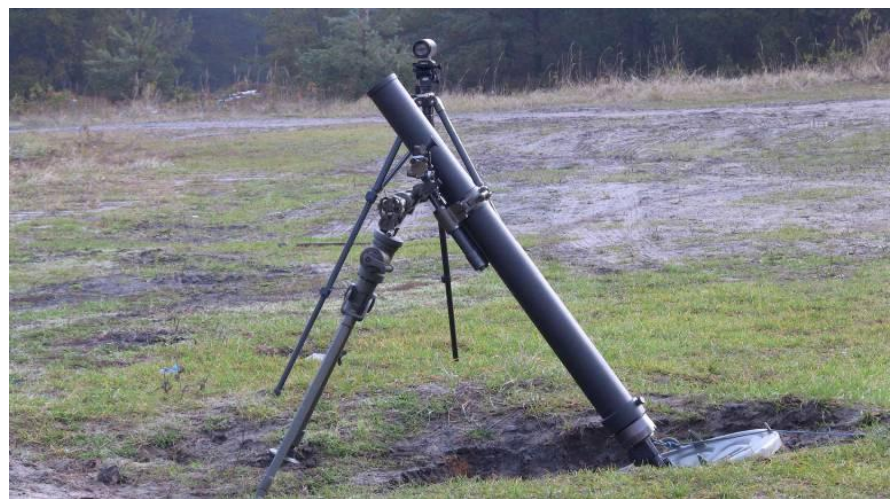

Fot. 4. Przygotowany do badań moździerz M-98.

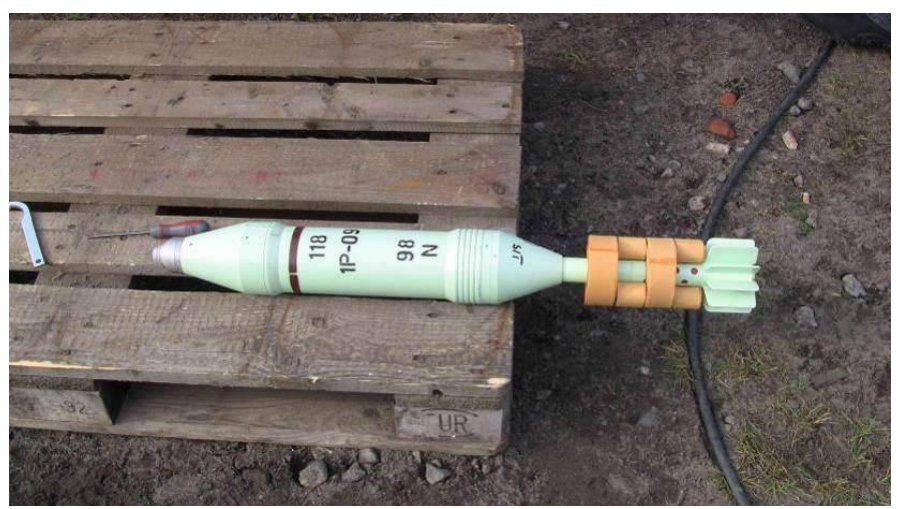

Fot. 5. Nabój moździerzowy z pociskiem dymnym przygotowany do strzelania. 
Mariusz Magier, Piotr Ruliński

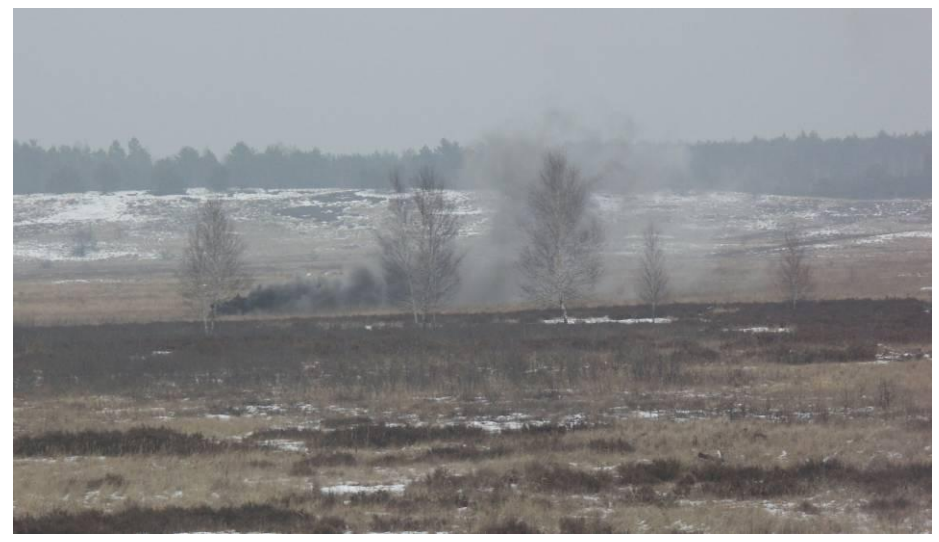

Fot. 6. Działajacy ładunek dymny po strzale.

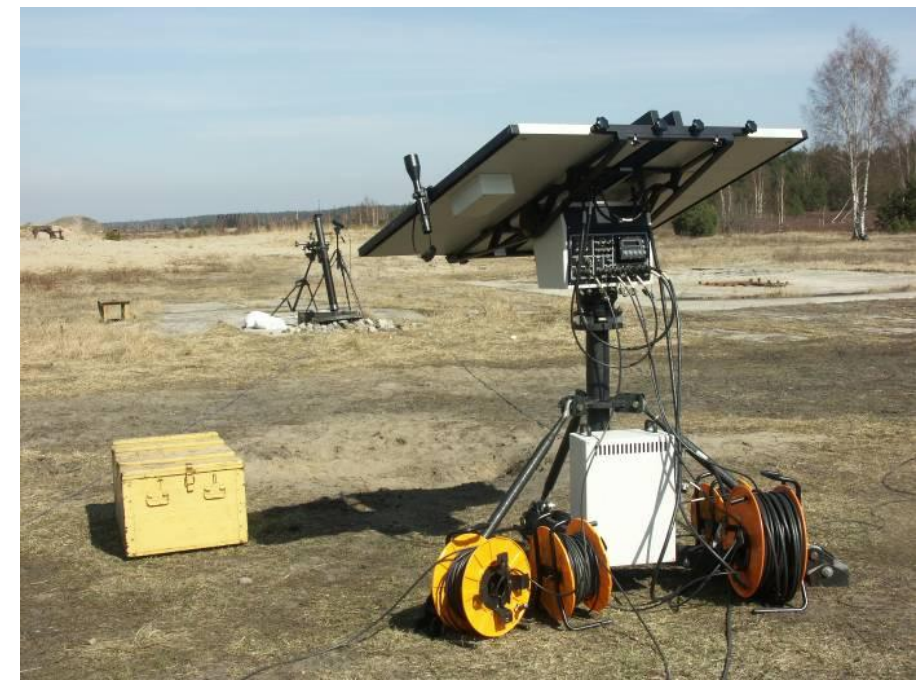

Fot. 7.98 mm moździerz M-98 i zestaw do pomiaru parametrów balistycznych.

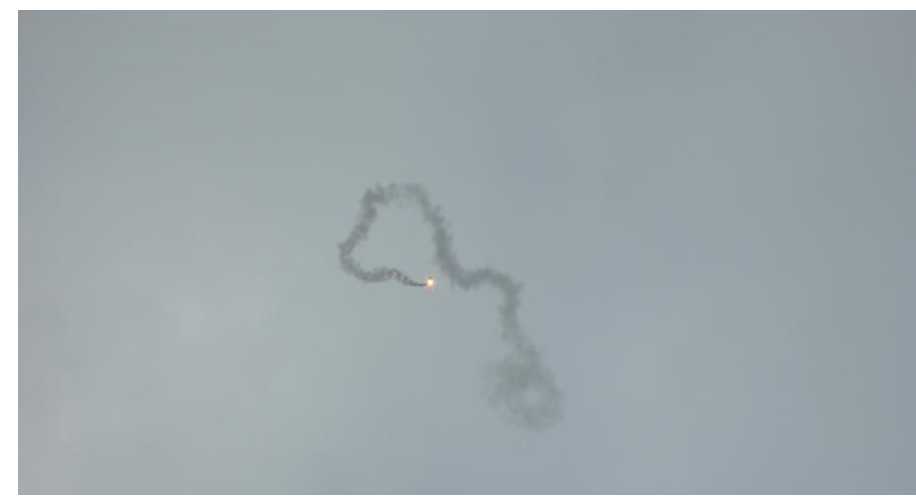

Fot. 8. Ładunek oświetlająy na torze lotu. 
The reliability firing tests of the special ammunition for $98 \mathrm{~mm}$ mortar M-98 Badania niezawodnościowe amunicji specjalnej do $98 \mathrm{~mm}$ moździerza M-98

\section{Badania w dniu 12.11.1014}

Naboje $\mathrm{z}$ pociskiem dymnym wystrzelone $\mathrm{w}$ skrajnej ujemnej temperaturze na ładunku $\mathrm{Nr} 1$, zaprogramowany czas rozcalenia zapalnika $26,26 \mathrm{~s}$, kąt celownika $75,4^{\circ}$. Tor lotu pocisku i moment rozcalenia śledzono zestawem balistycznym DR-5000.

Tabela 1 Wyniki badań

\begin{tabular}{|c|c|c|c|c|c|c|}
\hline Lp. & $\begin{array}{c}\mathrm{Nr} \\
\text { pocisku }\end{array}$ & $\begin{array}{c}\mathrm{p}_{\max } \\
{\left[\mathrm{kG} / \mathrm{cm}^{2}\right]}\end{array}$ & $\begin{array}{c}\text { Prędkość } \\
\text { początkowa } \\
{[\mathrm{m} / \mathrm{s}]}\end{array}$ & $\begin{array}{c}\text { Czas } \\
\text { dymienia } \\
{[\mathrm{s}]}\end{array}$ & $\begin{array}{c}\text { Wysokość } \\
\text { rozcalenia } \\
{[\mathrm{m}]}\end{array}$ & $\begin{array}{c}\text { Wytrzymałość } \\
\text { (funkcjonowanie) }\end{array}$ \\
\hline \hline 1 & 20 & 194 & 144,8 & 182 & 60 & prawidłowe \\
\hline 2 & 19 & 192 & 145,0 & 188 & 100 & prawidłowe \\
\hline 3 & 31 & 196 & 146,2 & 195 & 110 & prawidłowe \\
\hline 4 & 30 & 227 & 147,7 & 190 & 50 & prawidłowe \\
\hline 5 & 29 & 212 & 145,8 & 195 & 120 & prawidłowe \\
\hline 6 & 32 & 194 & 144,6 & 195 & 110 & prawidłowe \\
\hline 7 & 3 & - & 147,9 & 200 & 150 & prawidłowe \\
\hline 8 & 7 & - & 146,4 & 190 & 110 & prawidłowe \\
\hline 9 & 8 & - & 144,0 & 190 & 30 & prawidłowe \\
\hline 10 & 4 & - & - & - & - & $*$ * \\
\hline$*$ w zwiazku z niemożliwościq wkręcenia zapalnika MZR-96 w gniazdo \\
(uszkodzony gwint w czepcu balistycznym) pocisku nie wystrzelono
\end{tabular}

Obliczona średnia wysokość rozcalenia pocisku dymnego: $\mathrm{t}_{\text {sr }}=93 \mathrm{~m}$.

Naboje z pociskiem oświetlającym wystrzelone w skrajnej ujemnej temperaturze na ładunku $\mathrm{Nr}$ 1, zaprogramowany czas rozcalenia zapalnika 22,44 s, kąt celownika $77^{\circ}$.

Tabela 2 Wyniki badań

\begin{tabular}{|c|c|c|c|c|c|}
\hline Lp. & $\begin{array}{c}\mathrm{Nr} \\
\text { pocisku }\end{array}$ & $\begin{array}{c}\mathrm{p}_{\max } \\
{\left[\mathrm{kG} / \mathrm{cm}^{2}\right]}\end{array}$ & $\begin{array}{c}\text { Czas } \\
\text { świecenia } \\
{[\mathrm{s}]}\end{array}$ & $\begin{array}{c}\text { Prędkość } \\
\text { początkowa } \\
{[\mathrm{m} / \mathrm{s}]}\end{array}$ & $\begin{array}{c}\text { Uwagi } \\
\text { Funkcjonowanie }\end{array}$ \\
\hline \hline 1 & 9 & 215 & 55 & 148,0 & prawidłowe \\
\hline 2 & 10 & 206 & 55 & 147,5 & prawidłowe \\
\hline 3 & 37 & 206 & 49 & 146,6 & prawidłowe \\
\hline 4 & 19 & 217 & 50 & 147,8 & prawidłowe \\
\hline 5 & 5 & 194 & 54 & 145,7 & prawidłowe \\
\hline 6 & 4 & 210 & 53 & 147,2 & prawidłowe \\
\hline 7 & 24 & 202 & - & 146,1 & $*$ ) \\
\hline 8 & 23 & - & 50 & 145,2 & prawidłowe \\
\hline 9 & 35 & - & 55 & 147,8 & prawidłowe \\
\hline 10 & 36 & - & 55 & 147,2 & prawidłowe \\
\hline
\end{tabular}

*) - nie zadziałat zapalnik MZR-96 
Naboje z pociskiem oświetlającym wystrzelone w skrajnej ujemnej temperaturze na ładunku $\mathrm{Nr} 5$, zaprogramowany czas rozcalenia zapalnika 40,00 s, kąt celownika $58^{\circ}$.

Tabela 3 Wyniki badań

\begin{tabular}{|c|c|c|c|c|c|}
\hline Lp. & $\begin{array}{c}\mathrm{Nr} \\
\text { pocisku }\end{array}$ & $\begin{array}{c}\mathrm{p}_{\max } \\
{\left[\mathrm{kG} / \mathrm{cm}^{2}\right]}\end{array}$ & $\begin{array}{c}\text { Czas } \\
\text { świecenia } \\
{[\mathrm{s}]}\end{array}$ & $\begin{array}{c}\text { Prędkość } \\
\text { początkowa } \\
{[\mathrm{m} / \mathrm{s}]}\end{array}$ & $\begin{array}{c}\text { Uwagi, } \\
\text { Funkcjonowanie }\end{array}$ \\
\hline \hline 1 & 8 & 958,0 & 55 & 319,5 & $\begin{array}{c}41,22 \mathrm{~s}-\text { nastawa zapalnika, } \\
\text { prawidłowe }\end{array}$ \\
\hline 2 & 1 & 945,0 & 56 & 318,2 & prawidłowe \\
\hline 3 & 21 & 916,0 & 52 & 316,4 & prawidłowe \\
\hline 4 & 22 & 923,0 & 25 & 314,2 & $*)$ \\
\hline 5 & 29 & 923,0 & 55 & 315,5 & prawidłowe \\
\hline 6 & 30 & 968,0 & 55 & 316,8 & prawidłowe \\
\hline 7 & 2 & - & 55 & 316,0 & prawidłowe \\
\hline 8 & 6 & - & 34 & 316,5 & $* *$ ) \\
\hline 9 & 3 & - & 53 & 316,7 & $\begin{array}{c}40,52 \mathrm{~s}-\text { nastawa zapalnika, } \\
\text { prawidłowe }\end{array}$ \\
\hline 10 & 7 & - & 56 & 316,3 & $\begin{array}{c}40,50 \mathrm{~s} \text { - nastawa zapalnika, } \\
\text { prawidłowe }\end{array}$ \\
\hline
\end{tabular}

*) - rozpadnięcie się kostki oświetlającej po 20 sekundach świecenia na kilka części ** ) - rozpadnięcie się kostki oświetlajacej po 18 sekundach świecenia na dwie części

Naboje z pociskiem oświetlającym wystrzelone w skrajnej dodatniej temperaturze na ładunku $\mathrm{Nr} 5$, zaprogramowany czas rozcalenia zapalnika 41,22 s, kąt celownika $58^{\circ}$.

Tabela 4 Wyniki badań

\begin{tabular}{|c|c|c|c|c|c|}
\hline Lp. & $\begin{array}{c}\mathrm{Nr} \\
\text { pocisku }\end{array}$ & $\begin{array}{c}\mathrm{p}_{\max } \\
{\left[\mathrm{kG} / \mathrm{cm}^{2}\right]}\end{array}$ & $\begin{array}{c}\text { Czas } \\
\text { świecenia } \\
{[\mathrm{s}]}\end{array}$ & $\begin{array}{c}\text { Prędkość } \\
\text { początkowa } \\
{[\mathrm{m} / \mathrm{s}]}\end{array}$ & $\begin{array}{c}\text { Wytrzymałość } \\
\text { (funkcjonowanie) }\end{array}$ \\
\hline \hline 1 & 27 & 1041,0 & $*)$ & 325,2 & $\begin{array}{c}22,44 \mathrm{~s} \text { - nastawa zapalnika } \\
\text { prawidłowe }\end{array}$ \\
\hline 2 & 28 & 997,0 & 46 & 323,2 & prawidłowe \\
\hline 3 & 31 & 1004,0 & $* *)$ & 324,3 & prawidłowe \\
\hline 4 & 32 & 1016,0 & 47 & 323,7 & prawidłowe \\
\hline 5 & 33 & 1049,0 & 45 & 324,6 & prawidłowe \\
\hline 6 & 34 & 1037,0 & 51 & 325,8 & prawidłowe \\
\hline 7 & 38 & 1053,0 & 50 & 325,7 & prawidłowe \\
\hline 8 & 20 & - & 52 & 325,0 & prawidłowe \\
\hline 9 & 25 & - & 49 & 326,7 & prawidłowe \\
\hline 10 & 26 & - & 47 & 325,7 & prawidłowe \\
\hline
\end{tabular}

*) brak obserwacji wizualnej

**) zapalnik MZR-96 zadziatat (rozcalenie pocisku prawidtowe), brak palenia sie tadunku oświetlającego (brak zapalenia się kostki oświetlającej) 
The reliability firing tests of the special ammunition for $98 \mathrm{~mm}$ mortar M-98 Badania niezawodnościowe amunicji specjalnej do $98 \mathrm{~mm}$ moździerza M-98

\section{Badania w dniu 13.11.1014}

Naboje z pociskiem dymnym wystrzelone w skrajnej dodatniej temperaturze na ladunku $\mathrm{Nr} 5$, zaprogramowany czas rozcalenia zapalnika 48,68 s, kąt celownika $73^{\circ}$. Tor lotu pocisku i moment rozcalenia śledzono zestawem balistycznym DR-5000.

Tabela 5 Wyniki badań

\begin{tabular}{|c|c|c|c|c|c|c|}
\hline Lp. & $\begin{array}{c}\mathrm{Nr} \\
\text { pocisku }\end{array}$ & $\begin{array}{c}\text { Prędkość } \\
\text { początkowa } \\
{[\mathrm{m} / \mathrm{s}]}\end{array}$ & $\begin{array}{c}\text { Czas } \\
\text { rozcalenia } \\
{[\mathrm{s}]}\end{array}$ & $\begin{array}{c}\mathrm{p}_{\max } \\
{\left[\mathrm{kG} / \mathrm{cm}^{2}\right]}\end{array}$ & $\begin{array}{c}\text { Wysokość } \\
\text { rozcalenia } \\
{[\mathrm{m}]}\end{array}$ & $\begin{array}{c}\text { Wytrzymałość } \\
\text { (funkcjonowanie) }\end{array}$ \\
\hline \hline 1 & 21 & 319,5 & 48,49 & 1020 & 180 & prawidłowe \\
\hline 2 & 22 & 323,5 & & 997 & - & $\begin{array}{c}\text { śledzenie do 47 s } \\
\text { brak rozcalenia }\end{array}$ \\
\hline 3 & 37 & 323,6 & 48,33 & 1004 & 250 & prawidłowe \\
\hline 4 & 38 & 323,9 & - & 1020 & - & brak rozcalenia \\
\hline 5 & 27 & 325,5 & 48,38 & 1016 & 310 & prawidłowe \\
\hline 6 & 28 & 324,3 & 48,31 & 1037 & 280 & prawidłowe \\
\hline 7 & 44 & 326,0 & 48,69 & 1077 & 205 & prawidłowe \\
\hline 8 & 25 & 322,8 & 48,55 & 1057 & 136 & prawidłowe \\
\hline 9 & 35 & 324,2 & 48,24 & 1053 & 349 & prawidłowe \\
\hline 10 & 36 & 323,6 & 48,26 & 1057 & 275 & prawidłowe \\
\hline
\end{tabular}

Naboje $\mathrm{z}$ pociskiem dymnym wystrzelone $\mathrm{w}$ skrajnej ujemnej temperaturze na ladunku $\mathrm{Nr} 5$, zaprogramowany czas rozcalenia zapalnika 48,00 s, kąt celownika $73^{\circ}$. Tor lotu pocisku i moment rozcalenia śledzono zestawem balistycznym DR-5000.

Tabela 6 Wyniki badań

\begin{tabular}{|c|c|c|c|c|c|c|}
\hline Lp. & $\begin{array}{c}\mathrm{Nr} \\
\text { pocisku }\end{array}$ & $\begin{array}{c}\text { Prędkość } \\
\text { początkowa } \\
{[\mathrm{m} / \mathrm{s}]}\end{array}$ & $\begin{array}{c}\text { Czas } \\
\text { rozcalenia } \\
{[\mathrm{s}]}\end{array}$ & $\begin{array}{c}\mathrm{p}_{\max } \\
{\left[\mathrm{kG} / \mathrm{cm}^{2}\right]}\end{array}$ & $\begin{array}{c}\text { Wysokośćc } \\
\text { rozcalenia } \\
{[\mathrm{m}]}\end{array}$ & $\begin{array}{c}\text { Wytrzymałość } \\
\text { (funkcjonowanie) }\end{array}$ \\
\hline \hline 1 & 26 & 314,0 & 48,55 & 939 & 104 & prawidłowe \\
\hline 2 & 33 & 316,8 & 48,72 & 987 & 74 & prawidłowe \\
\hline 3 & 23 & 314,8 & 48,63 & 961 & 155 & prawidłowe \\
\hline 4 & 24 & 312,5 & 48,71 & 952 & 11 & prawidłowe \\
\hline 5 & 5 & 314,4 & 48,46 & 939 & 97 & prawidłowe \\
\hline 6 & 6 & 314,8 & 48,52 & 945 & 207 & prawidłowe \\
\hline 7 & 9 & 317,5 & 48,57 & 981 & 129 & prawidłowe \\
\hline 8 & 10 & 317,5 & 48,65 & 990 & 147 & prawidłowe \\
\hline 9 & 1 & 314,5 & 48,58 & 952 & 80 & prawidłowe \\
\hline 10 & 2 & 315,2 & 48,74 & 955 & 39 & prawidłowe \\
\hline
\end{tabular}


Naboje $\mathrm{z}$ pociskiem dymnym wystrzelone $\mathrm{w}$ temperaturze normalnej na ładunku $\mathrm{Nr} 5$, kąt celownika $73^{\circ}$. Tor lotu pocisku i moment rozcalenia śledzono zestawem balistycznym DR-5000.

Tabela 7 Wyniki badań

\begin{tabular}{|c|c|c|c|c|c|}
\hline Lp. & $\begin{array}{c}\mathrm{Nr} \\
\text { pocisku }\end{array}$ & $\begin{array}{c}\text { Nastawa zapalnika } \\
\text { MZR-96 } \\
{[\mathrm{s}]}\end{array}$ & $\begin{array}{c}\text { Czas } \\
\text { dymienia } \\
{[\mathrm{s}]}\end{array}$ & $\begin{array}{c}\text { Prędkość } \\
\text { początkowa } \\
{[\mathrm{m} / \mathrm{s}]}\end{array}$ & $\begin{array}{c}\text { Wytrzymałość } \\
\text { (funkcjonowanie) }\end{array}$ \\
\hline \hline 1 & 18 & 48,00 & 190 & 322,5 & prawidłowe \\
\hline 2 & 16 & & 200 & 320,8 & prawidłowe \\
\hline 3 & 15 & \multirow{3}{*}{48,68} & 180 & 321,2 & prawidłowe \\
\hline 4 & 12 & & 182 & 321,2 & prawidłowe \\
\hline $5 n n n n n n$ & & & 186 & 322,5 & prawidłowe \\
\hline
\end{tabular}

Naboje $\mathrm{z}$ pociskiem oświetlającym wystrzelone $\mathrm{w}$ temperaturze ujemnej na ładunku Nr 5, kąt celownika 83 ${ }^{\circ}$, nastawa zapalnika MZR-96 - 48,62 s .Tor lotu pocisku i moment rozcalenia śledzono zestawem balistycznym DR-5000.

Tabela 8 Wyniki badań

\begin{tabular}{|c|c|c|c|c|c|}
\hline Lp. & $\begin{array}{c}\mathrm{Nr} \\
\text { pocisku }\end{array}$ & $\begin{array}{c}\text { Natężenie } \\
\text { oświetlenia } \\
{[\text { lux] }}\end{array}$ & $\begin{array}{c}\text { Czas } \\
\text { świecenia } \\
{[\mathrm{s}]}\end{array}$ & $\begin{array}{c}\text { Prędkość } \\
\text { początkowa } \\
{[\mathrm{m} / \mathrm{s}]}\end{array}$ & $\begin{array}{c}\text { Uwagi } \\
\text { Funkcjonowanie }\end{array}$ \\
\hline \hline 1 & 16 & $0,10-0,19$ & 51 & 324,0 & prawidłowe \\
\hline 2 & 18 & $0,16-0,35$ & 52 & 324,8 & prawidłowe \\
\hline 3 & 17 & $0,26-0,55$ & 50 & 323,0 & prawidłowe \\
\hline 4 & 14 & $0,25-0,30$ & 55 & 323,7 & prawidłowe \\
\hline 5 & 14 & bez pomiaru & 50 & 323,7 & prawidłowe \\
\hline
\end{tabular}

\section{Podsumowanie}

Obliczone wartości średnie ocenianych parametrów taktyczno-technicznych zestawiono w tabeli 9. Spełniają one wymagania zawarte w WZTT.

Wystrzelono:

- 35 pocisków dymnych. Prawidłowo działały 33 pociski. Prawdopodobieństwo poprawnego działania naboju dymnego wyniosło $94,3 \%$,

- 35 pocisków oświetlających. Prawidłowo działało 31 pocisków. Prawdopodobieństwo poprawnego działania naboju oświetlającego wyniosło $88,6 \%$. 
The reliability firing tests of the special ammunition for $98 \mathrm{~mm}$ mortar M-98 Badania niezawodnościowe amunicji specjalnej do $98 \mathrm{~mm}$ moździerza M-98

Tabela 9 Wartości średnie ocenianych parametrów taktyczno-technicznych

\begin{tabular}{|c|c|c|c|c|c|c|}
\hline \multirow{2}{*}{$\begin{array}{l}\text { Rodzaj } \\
\text { pocisku }\end{array}$} & \multirow{2}{*}{$\begin{array}{c}\mathrm{p}_{\max } \\
{\left[\mathrm{kG} / \mathrm{cm}^{2}\right]}\end{array}$} & \multirow{2}{*}{$\begin{array}{c}\text { Prędkość } \\
\text { początkowa } \\
{[\mathrm{m} / \mathrm{s}]}\end{array}$} & \multicolumn{2}{|c|}{$\begin{array}{l}\text { Czas } \\
{[\mathrm{s}]}\end{array}$} & \multirow[b]{2}{*}{ Ładunek } & \multirow[b]{2}{*}{ Temperatura } \\
\hline & & & $\begin{array}{l}\text { dymienia / } \\
\text { świecenia }\end{array}$ & rozcalenia & & \\
\hline / dymny & $202,5 \pm 36,5$ & $145,8 \pm 3,3$ & $191,7 \pm 12,5$ & $26,66 \pm 0,77$ & \multirow{2}{*}{ Nr 1} & \multirow{3}{*}{$243 \mathrm{~K}$} \\
\hline \multirow{3}{*}{ oświetlający } & $207,1 \pm 20,4$ & $146,9 \pm 1,9$ & $52,9 \pm 6,1$ & $22,72 \pm 0,07$ & & \\
\hline & $938,8 \pm 55,5$ & $316,6 \pm 2,8$ & $\begin{array}{c}49,6 \pm \\
21,8 \\
\end{array}$ & $40,87 \pm 0,31$ & \multirow{4}{*}{$\mathrm{Nr} 5$} & \\
\hline & $1028 \pm 58$ & $325,0 \pm 2,0$ & $48,4 \pm 6,0$ & $40,62 \pm 0,84$ & & \multirow{2}{*}{$323 \mathrm{~K}$} \\
\hline \multirow{2}{*}{ dymny } & $1034 \pm 53$ & $323,7 \pm 3,6$ & - & $48,41 \pm 0,38$ & & \\
\hline & 38,4 & $315,0 \pm 3,2$ & - & $48,61 \pm 0,18$ & & $243 \mathrm{~K}$ \\
\hline
\end{tabular}

\section{Literatura}

[1] Sprawozdanie z realizacji Projektu Celowego nr 347/BO/B zgodnie z umową nr 148486/C-T00/2007 z 02.08.2007 r. pt. „Nabój z pociskiem dymnym do 98 mm moździerza M-98". - sprawozdanie niepublikowanie - archiwum WITU.

[2] Sprawozdanie z realizacji Projektu Celowego nr 348/BO/B zgodnie z umową nr 148485/C-T00/2007 z 02.08.2007 r. pt. „Nabój z pociskiem oświetlającym 98 mm moździerza M-98”. - sprawozdanie niepublikowanie - archiwum WITU.

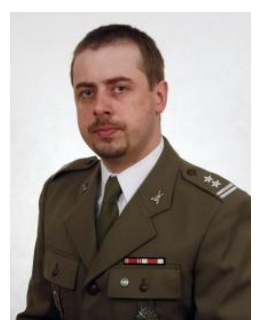

Pptk dr inz. Mariusz Magier. Ukończyt WAT w 1997 roku. Od 1999 roku petni stużbe w Wojskowym Instytucie Technicznym Uzbrojenia, obecnie na stanowisku Kierownika Zaktadu Uzbrojenia Artyleryjskiego. Specjalizuje się $w$ zakresie konstrukcji $i$ badań przeciwpancernej podkalibrowej amunicji czołgowej.

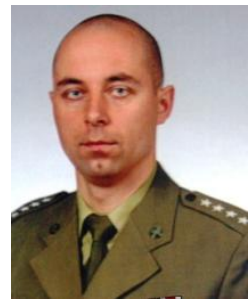

Kpt mgr inz. Piotr Ruliński. Ukończyt WAT w 2003 roku. Od 2012 roku petni stużbe $w$ Wojskowym Instytucie Technicznym Uzbrojenia, obecnie na stanowisku asystenta $w$ Zaktadzie Uzbrojenia Artyleryjskiego. Specjalizuje sie $w$ zakresie konstrukcji $i$ badań elektronicznych zapalników czasowych i zbliżeniowych do amunicji moździerzowej i artyleryjskiej. 